\title{
Between Clarity and Novelty Implementation in Indonesia Online Media According to the Principle of Journalist
}

\author{
MARIKO RIZKIANSYAH \\ MUSLIKHIN \\ MARGANA WIRATMA \\ Bina Nusantara University, Indonesia
}

\begin{abstract}
The number of online media in Indonesia has been increasing in the last five years. The developments of the number of online mass media are followed by the increasing of share information through social media, including real or fake news. Online mass media activity to keep the balance between actuality and accuracy when they searching and publishing news to the public. This research aims to find how the process of journalist's works between accuracy and actuality in the online mass media in Indonesia. Another purpose of this research is to find out how the journalist deals with accuracy and actuality according to the element of journalistic principles. The research was conducted by observations and interview on the online mass media managers in Indonesia which are detik.com, kompas.com, suara.com and liputan6.com. The result of the research is online media using elements of journalism to publish their news to keep novelty and clarity. They also convinced that it is hard to implement the element of journalism one hundred per cent because there are so many restrictions, such as the influences of owner interest and policy from company or government. Therefore, profit from user become their main target than create a truth of information based on the element of journalistic principles.
\end{abstract}

Keyword: Online media, novelty, clarity, journalist, Indonesia.

\section{INTRODUCTION}

The numbers of internet users have been increasing enormously, from 3.7 billion in 2017 to 4.5 billion in 2019. The internet users are 711.3 million or 84 per cent of the total population in the world, and 470.5 million penetration of social media users (wearesocial.com, 2020). China is the country that is using the internet the most with the total number of 642 million. The number of 642 million represents 22 per cent of people using the internet in the world. India is the country with the lowest penetration with 19 per cent, but the highest yearly growth rate. While the United States, Germany, France, U.K and Canada are the country with the highest penetration of internet, over 80 per cent of the population has an internet connection (internetlivestats.com, 2018).

Statistically, Internet users in Indonesia are not so different from the other countries whereas the increase of internet user risen dramatically. The percentage of internet user was slightly increasing from 89, 32 million in 2015 to 97, 07 million in 2016. In 2017, internet users have dramatically increased to 104, 96 million. The statistica.com predicts the increases in internet users would rise to 139, 4 million people by the year 2022 (statista.com, 2018).

Online news media is growing rapidly although conventional media is still the most important media in Indonesia (Nugroho \& Syarief, 2012). According to Indonesian internet service provider Association, the increasing number of Internet users from 132.7 million users in 2016 to 254.16 million users in 2018 supporting the development of online news media. 
The total penetration reached $64.8 \%$ of Indonesia's 264.16 million total populations (Asosiasi Penyelenggara Jasa Internet Indonesia (APJII), 2019).

The increase of internet user is followed by the emerging of online mass media. There are a lot of new online media in Indonesia. According to the Press Council of Indonesia, there are $\mathbf{4 3 . 4 0 0}$ online news media in Indonesia even though Press Council of Indonesia only listed 234 (kompas.com, 2016). Four most prominent online mass media in Indonesia are tribunews.com, detik.com, liputan6.com, and kompas.com (Alexa.com, 2018).

Currently, the news production process has changed considerably as a modification in the definition of journalism or the understanding of news (Domingo et al., 2015). In the digital age, one of the standard changes in news production is to emphasize greater weight for the interest of the audience (Crain, 2008). According to Anderson (2018), the increasing audience participation made journalists and editors more sensitive to the implications of what their audiences are reading, and why. When the audiences have a free choice, they also would create their news agenda different from the status quo - setting what stories they want to appear as news, and dictating the contents of the news presented to them (Stray, 2018). If the news is a collective product of the system, then the behaviour of news is a reflection of collective and/or institutional behaviour (Wijaya, 2019).

The development of technology creates a dramatic impact on journalism skill, especially for the journalist who works in the online media company. A journalist becomes an individual worker or newsroom who work with four cores of the journalistic task (selecting, gathering, writing and editing) in the more or less exclusively worldwide web (Bardoel \& Deuze, 2001). The journalist does not only distribute their work to the online media but also the other mass media in the group, such as radio and television. So, journalists have to upgrade their skill into a combination of competencies at least for three types of mass media such as online media, radio, and television.

The improvement of internet technology on online mass media affects the pressure for the journalist. They have to work for three or more media in a company group of media. A journalist must able to create the information into the news for a different style of mass media which are online media, radio, and television (Filak, 2015). Whereas they have to keep the main journalistic principle which is the news should be accurate.

Based on the reason for those backgrounds, researchers decided to study the process of a journalist in keeping the accuracy and actuality when they create information to be a piece of news. The other purpose of the research is to find out how the journalist is dealing with the situation from accuracy and actuality against ten elements of journalism.

\section{LITERATURE REVIEW}

\section{a. Journalism in Online media}

Online media is one of the media which publish information through the internet. Therefore, a user needs to have an internet connection to access online media. The Internet has opened the gate of information. Therefore, the information spread like floods (Friedman, 2006). The media's online gives a chance to citizen instead of a journalist to share and publish information by the online mass media to the public. Moreover, online mass media seldom publish news or information that viral to the public. The story that went viral is usually not from a reporter but contributed by the citizen journalist.

According to John Vivian, online media have the characteristics such as the core of the message that contains in online media, the navigability to move from one page to another page, the externals link (interconnectivity) to other sites, sitemap and loading time (Vivian, 
2008). Another characteristic of online media is interactivity from user to mass media. The interactivity means that the user can communicate to mass media or change the content of mass media. This interactivity leads the online media to other conventional mass media such as newspaper, radio, and television because they have no interactivity (Filak, 2015). Communication usually is done as two side communication, and the audience gives feedback to mass media.

Splichal and Sparks offer the best of three definitions around journalism (Burns, 2012). First, describes journalism as a professional journalist as someone who earns his or her living from the activity of journalism, the second definition is underpinned by the notion of technical mastery which separates journalists from those who are merely published, the third definition is couched in terms of social responsibility 'involving patterns of behaviour which are rooted in that occupation but which have implications for the general department of the professional individual'. Journalists could be defined as the profession who their jobs looking for the information based on news value, manage the information become the news depend on the style of media and publish to people through mass media such as newspaper, radio, television or online media. Rosen says that journalism's strengths are in reporting, verification, and access (Borden, 2013).

According to Ward, there are four stages of the journalistic process which are researching, reporting, story constructing, and publishing (Filak, 2015). Researching is the first phase of journalists to looking for the best information. The research was done through observation with people or find information from other media. The second phase is reporting. This phase encouraging reporter to find data from their resource. Interview person or observation is the best way for a reporter to collect the data. The third phase is story construction. A reporter writes the script and selects the best angle for their story. The last phase is publishing. This phase has a different strategy for each of media for example newspaper publish their story every morning while television broadcast their news every hour.

The development of internet technology has influenced journalism. The emerging of online journalism is one of the effects of the increase in using the internet in society, including employment in the mass media company. Online journalism definition has developed from a digital version of news publishing to a source of endless amounts of the original content found only on the internet (Fusco, 2010). Online journalism is a new approach in journalism that affects journalist skill. Many conventional journalists have upgraded their skill and competencies on online journalism. Moreover, the era of media convergence when people using the internet as a source of information more than other media cause the journalist to learn journalistic in three platforms which are radio, television and online. Stephen Quin and Lamble suggest journalist learn more around visual thinking, audio editing, writing for radio, writing for online, writing for visual and image editing to support the increasing of journalism skill or known as a skill for journalism multimedia (Quinn \& Lamble, 2008).

\section{b. Clarity and Novelty (Timeliness) News Value}

The process of information transforming into the news is generally divided into two parts which are gathering news and production news (Hudson \& Rowlands, 2018 ). Gathering news means finding the topic for news, relevant source, writing script and recording a visual while production news related to publishing news to the user from a website. The process of journalism involving their sharpness, intelligent and balance to get news. They also put on the 
perspective of what to discover, found and report (Septiawan, Siti Suriani, Firmansyah \& Engkus, 2020). Mike Ward identifies four main elements in the gathering process when the reporter is doing research and reporting and how the use of online supports:

a. Finding information - searching for information from documents, data, audio, visual and photographs

b. Finding people - this element named the person, tapping into a debate, person current thinking, trend and fashion from person or group.

c. Checking information- using the online reference to check the actuality of the information.

d. Analyzing information - some particular data, internet support journalist to analysis information and give the data (Ward, 2013).

When reporters are searching for information that could be processed into the news, they need the measurement to figure out whether the information could change into news or not. The guidance for the reporter is known as news value. According to Bednarek and Caple (2017), news value defined as values in the information recognized in the literature as newsworthiness.

News is a product managed in the newsroom. So, neutral is one of the important things from news to be believed by society. Neutral means that the information of the media must cover both sides (Muhammad Ruslan \& Das'ad, 2019). There are several values to identify information as a piece of news which is clarity and novelty. Clarity means that information should be accurate and clear therefore the information must contain the truth because the purpose of mass media is to publish accurate information. Novelty is also known as timeliness, means that the information must be new or actual. So, each of mass media tries to find the information faster than any other media to gain prestige in the public perceptions (Brighton \& Dennis, 2007).

According to Bednarek and Caple (2017), news values work on three dimensional which are material reality holds potential news value for a given community (Material), news workers and audience members have beliefs about news values and newsworthiness (Cognitive), news values are applied as selection criteria in journalist practice (social) and news values can be communicated through discourse (Discursive).

Gans has four theories that cause the reporter to create selecting and decisions for publishing information which are:

a. Journalistic judgment, a decision from reporter to change information into news.

b. Organizational requirements, including commercial decisions, owner side.

c. The event/ mirror theory, the idea that a journalist is holding the mirror in nature.

d. External determinism involves factor such as ideology, technology, economy (Brighton \& Dennis, 2007).

\section{c. Element principle journalism of Bill Kovach and Tom Rosenstiel}

A journalist works related to public opinion, whether the information is true or false. Therefore, a journalist must have guidance to create better quality from the journalist's report to avoid tricking public. Kovach and Rosenstiel (2014) create the element of journalism for a journalist to work in the newsgathering. The elements of journalism are: 
a. Journalism's first obligation is to the truth

b. Its first loyalty is to citizens

c. Its essence is a discipline of verification

d. Its practitioners must maintain an independence from those they cover

e. It must serve as a monitor of power

f. It must provide a forum for public criticism and compromise

g. It must strive to make the significant interesting and relevant

h. It must present the news in a way that is comprehensive and proportional

i. Its practitioners should exercise their conscience

j. Citizens have rights and responsibilities when it comes to the news as welleven more so as they become producers and editors themselves.

Those elements above are expected to be the guidance of a journalist when they are searching for information and publish it to the public. Therefore, a journalist should avoid fake news or the bias information for specific interest or purpose.

\section{METHODOLOGY}

This study used the same theoretical as Yang and Cannon (2017). Their research was around editor select stories based on proximity news values in the online publication. According to this research, an editor does not rely on established news value to select news stories. Editors prefer news categories than news value to decide the stories published to the public. Moreover, news categories closely match with what the readers want.

This research uses qualitative as an approach to research. The qualitative research means that designed to explore the human elements of given topics, where specific methods are used to examine how individuals see and experience the world. Qualitative approaches often to explore the phenomena and capture individuals' thoughts, feelings, interpretations of meaning and process (Given, 2008). According to Hennink, Hutter and Bailey (2010), qualitative research is an approach that allows a researcher to examine people's experience detail, by using a specific set of research methods such as in-depth interview, focus group discussions, observation, content analysis, visual methods and life of biographies.

The analysis of this research was obtained from empirical research of three online media in Indonesia that are detik.com, kompas.com, and liputan6.com by interviewing the journalist who works in those media. The reason for focusing on detik.com, liputan6.com, and kompas.com is that they are the most prominent online media from the user in Indonesia (Alexa.com, 2018).

Some topics to be interviewed to the interviewees are their understanding and perception around news value, the work process of journalist and their priority between novelty and accuracy against the element of journalism when the pressure of publishing online media comes. Therefore, the search questions are:

a. How the understanding of workers of novelty, clarity, and element of journalism in the online media?

b. How the implementation of news value (novelty and clarity) through the element of a journalist to publish news in online media in Indonesia? 


\section{FINDING AND INTERPRETATION}

Our study shows mostly they have the same understanding of clarity and novelty but different when they implement in the practice. Researchers discuss more in this study around the understanding of stakeholder in online media around clarity, novelty and the implementation in their online media.

\section{a. The Understanding of Clarity in the Online Media}

The definition of clarity in the term of online media is the information must be true and accurate. So the information must be precise for users to read. In the online media in Indonesia, clarity still becomes the first role of editorial when they decide to publish a piece of news to the public. According to Informant 1, liputan6.com decides that it is better to be late than to create false news.

We cannot get the news if the source is from other media. Otherwise, we confirm it ourselves. Sometimes is too late because it must be that way. Liputan6.com still guards that principle until now. Checks, re-checks, and confirmation are still being executed.

Informant 2 assumes that there is a shifting in determining the feasibility of the news. Therefore, it should be changing the understanding of clarity in the online mass media. His argument is the online media selecting news with precede high traffic than clarity but changes because of the development of people in online media.

But it turns out now, the smarter people read online media, the more they distinguish real and fake news." So we must make the verified content first and then publish it. With the old-time model approach, we convinced that the reader would not read our news.

Meanwhile, Informant 3 claims the definition of clarifying in the kompas.com is to clear the problem in social media. The purpose of news to be published because kompas.com must clarify the fake information or noise sounds in social media. Therefore, the public knows the truth about their information.

Our principle is not to increase the noise but to answer the problem or clarify the problem. So when there is a crowd (in social media), that is a problem. True or false. We cannot proclaim only based on social media. Social media say this ... we cannot do that (- instantly reported). What we do is we have to answer whether the crowd is right or not.

\section{b. Understanding of Novelty on Online Media}

Most stakeholders in online media have a new perspective on the novelty that makes it different from conventional media such as television and radio. Media like radio and television think that novelty is the fastest information to share with the public because they have limited time, so the novelty is precious. However, according to informant 4, novelty means that the actual news comes from the exclusive news with a different angle. 
If the news is running or being viral, the novelty is selective to the news angle. For example, the point of view of an event is divided, so it becomes diverse that resulting in new content. Although the story is running, the journalist must find the different angle of the events (Informant 4).

Although the perspective of informant 1 related with other stakeholders in the different media but Informant 3 has another perspective around the novelty in the mass media. His argument is that novelty in the mass media is unclear and hard to define because the behaviour of the user is what decides whether the news includes novelty or not.

"Novelty in print media is daily while in the online media is not clear anymore. It could be a novelty today, for people who do not follow, but it can be a novelty if they follow tomorrow. Therefore, the age of news in the online media becomes very relatives about the novelty (Informant 3 ).

While novelty journalists experience a change of meaning, in the era of conventional media, novelty is interpreted as new information and has not been published in other media. While for online media journalists, novelty is information that has not been published in the media where the journalists work even though other media have published.

\section{c. The Implementation of Clarity and Novelty in Online Media}

Although the stakeholders of online media have related perspective about clarity, they have a different strategy to implement the clarity in the newsroom on online media. One of the famous strategies that being guidance for every stakeholder in online media is process journalism. According to informant 1, process journalism is the process of publishing news gradually. When they find the fresh information and then they would publish it to the public even though the information is not complete. Afterwards, they will complete the information after some clarification from authority or the competent side.

Journalism process occurs due to speed pursuit. News published first and then various errors on typing or clarification on the source is corrected in the next news. In addition to the subsequent news also contains other sources as additional information (Informant 1).

Journalism process in the making of the truth, in which truth is being created or processed, so it has not reached its original truth (Informant 2).

Confirmation and clarification are needed by the stakeholder in the news office to justify the information that is worthy to publish or to keep. In the process of clarity for online media, confirmation and clarification is important. Both of them feel that in online media, both novelty and clarity are produced simultaneously.

In the old strategy, the news is the result of confirmation and verification. The process of confirming one story involves many people. Online media is different. In the online media, the verification and confirmation process is news (Informant 1) 
Clarity is also essential to reach credibility from the public so that the media can reach a lot of reader due to the truthiness of information. In order to reach the reader, the information must clear from the fake news. Informant 2 assumes that readers are smarter in online media now.

Readers are aware of the correct content nowadays when there are verified and confirmed data, readers will return to it. If the media content is only a glance, no confirmation, no clear source, it will not be read anymore by the reader (Informant 3).

When they find a situation such as having viral information from social media, the online media must check and have a clarification to the main source. Another strategy is analyzing the member who spread the viral information. If the followers of the source are under ten people, then they should avoid publishing the information because they are afraid that account is a robot that created content just for the sake of spreading the fake news in social media. This strategy is different when they copy news from famous social media.

If news comes from social media then we try to confirm by contacting the person. But, did not make confirmation when it comes to famous people like Fahri Hamzah, Fadli Zon, and others. Many of the characters make social media as a medium for himself speaking to the public (Informant 1).

The implementation of novelty in online media is not far from clarity implementation. They processed continuously at the same time. One moment of news can be spread into pieces of topics following the novelty that a reporter should report from the field or location.

First, we publish events and then update it by interviewing police, witnesses, or create a feature and interviewing his family. All stages flow into some news. After all the news is completed, then we can combine and republish it for the reader who did not follow the event from the beginning (Informant 4).

When they process novelty in the news video online, it is not far away as the text model. It could be four or five news with different angles from one event of the news that being viral. But the problem is having a new visual. Sometimes they change the visual with a photo if the quality of the video is too large for their website.

On the other hand, readers like photos and videos. So the editorial has a journalistic interest to give evidence (Informant 2).

\section{d. The implementation of novelty and clarity due to journalist element Bill Kovach}

There are differences and similarities when the editorial decides information into a news story based on the value of novelty and accuracy and then adjust it with the journalistic elements of Bill Kovach between conventional media and online media. All stakeholders have found it challenging to apply Bill Kovach's element in the novelty and accuracy of the news because it was hit by other interests such as the policy of the owner of the group. 
Print media often cannot qualify journalism from Bill Kovach. For example, the verification process comes from the print media, so it is not fully met. Especially in Indonesia, there a lot of journalism "Mouth" (-journalism that only record and publish people-talk) so what is said is regarded as truth without a verification process. Then I think the journalist Bill Kovac's element is the basis of the journalistic work (Informant 3).

The role of media to meet public information is also diminished in online media policies. Although Indonesia online media are claimed not too favoured by specific groups, the loyalty of providing ideal information to the public such as education and development to shift towards information for increased traffic.

Loyalty to the public is difficult to implement fully. Often loyalty is to the traffic of the web, on the page view. Sometimes we know this news is not important and trivial, but it is liked by the reader even commercially attractive, then the news is loaded or uploaded (Informant 4).

The media must be critical to government policies or social control. This is one of the functions of the mass media. But as the online media progresses, the critical role of the mass media becomes diminished by the policies of the media owners group.

Liputan6.com does not criticize the issue strictly. This is because the group liputan6.com wants to stay neutral with all parties so that although not affiliated with certain political parties but news from liputan6.com does not want to cause a commotion with other parties (Informant 1).

Even so, online news does not mean that it does not meet the needs of the community. Precisely, online news is trying to display the news following the interests of the community. For that, the function of mass media is no longer as social criticism or government but as a medium of education or a source of inspiration to the community.

If we used to campaign to make Indonesia more optimistic, the content in media should not show the news that is not optimistic like the failure of development, the country destroyed by corruption. Therefore, the media should do a massive campaign with the theme of multiplying the news on the topic of inspiration (Informant 2).

\section{DISCUSSION}

Online media in Indonesia always try to hold full news value in every news. According to the understanding of online media editors, news value is a requirement to choose events to become news. News value cannot be abandoned because it concerns the credibility of the media. If the news value is abandoned, the reader will give a bad image to the media and move on to other media. Understanding of this news value began to shift from the initial understanding of news value. According to Galtung and Ruge, news value is simply defined as an assessment of how important an event is to a news story compared to other events (Rasyid \& Siagian, 2017). News value itself will continue to change along with the development of 
technology, readers, and the audience itself. According to Donsbach, news value is involved in subjective judgments and has never been placed as an objective criterion whereas Hall sees the value of news as part of an ideology constructed by the ruler looking at the world itself (Harcup \& O'Neill, 2016).

In running the news value for clarity of the news, some editors of verified by Dewan Pers (press council in Indonesia) online media in Indonesia insist on keeping running confirmation and clarification. For them, clarification and confirmation is one news value that distinguishes high and low reputed mass media by online readers. If an online media does not clarify and confirm, it will undoubtedly be abandoned because online readers at this time have been critical and often do supervision of news content reported by the mass media (Pavlik, 2001).

Although every mass media in Indonesia holds clarification and confirmation as a way to gain clarity of an event, in practice, each editor has their strategy to adjust the value of news clarity with the nature of online media that rely on speed. Various online media often use the strategy to upload the events first and then confirm and clarify it with the competent parties. However, this strategy does not apply when the media get a viral event through social media. To that end, they must clarify in advance to the parties related to the information and then evaluate to decide the feasibility of the publication of the information.

The understanding of online media editor to the value of novelty of an event is also the same. They have a new understanding of novelty that is different from conventional media. When novelty in the era of radio and television is the latest events published to the public, then in the era of online media, novelty is defined as a new event with a broken angle to form another novelty. In addition, the latest information from an event that is covered indepth and continuously is also included in the news value of novelty.

The implementation of the novelty of news value strategy in the publication of the news is no different. Each editor has the same strategy of dividing an event into a small angle and then publishing it according to the latest information they get from a reporter in the field. Similar strategies are also applied in the form of photos and videos. They call this process of journalism which is the process of searching for news continuously to create complete news in the future.

The application of news value for novelty and clarification in the context of journalism element is complicated to be applied entirely in online media in Indonesia. This is caused by the difficulty of online media in Indonesia to get away from the interests of owners of the media group. Critical tone of online media is bumped by group owners affiliated with a particular party or government so often only rely on clarification and confirmation based on a person's statement without trying to investigate more in-depth into the statement.

In addition, journalist elements should be loyal to the public experiencing the constraints of the nature of online media who prefer to pursue traffic rather than benefit the news to the public. Advertising revenue from reader traffic is the main reason for online media to pursue information that is expected to get a lot of traffic from online readers. For that, they must be keen to understand the reader's desire for a story. In market terms, the media is a company that produces and distributes a piece of news to a well-defined region (Allen, 2002).

The editors in Indonesian online media apply news value of clarity and novelty to every news reporting. The application is different from conventional media such as radio or television. The differences lay in the journalism of the process of seeking clarification and confirmation gradually until the news is composed entirely and then republished. 
There has been a change in the implementation according to online media characters and the reader's character. Constraints such as the policy of owners of media groups become a barrier to the media to be critical. In addition, online media is also hit by the condition of society. People's desire for simple news causes online media to focus only on catching readers' traffic to forget the role of the media as social and educational control. Therefore, the function of mass media online has changed from media for people to media for commercial because they think people are the main profit from their company.

\section{BIODATA}

Mariko Rizkiansyah is a specialist content lecturer in the mass communication department, Bina Nusantara University. His research interest area in journalism, mass media and social media. He had 6 years' experience as a mass media worker at MNCTV. Email: mariko.rizkiansyah@gmail.com

Muslikhin is the head of a broadcasting laboratory at Bina Nusantara University. He also works as a producer at Indosiar television in Indonesia. His research interest around journalism, media broadcasting and politics. Email: mdmuslihin@gmail.com

Margana Wiratma is a lecturer at Bina Nusantara University. His research interest around management and mass media. He is also former of journalism in the Tempo Magazine. Email: margana@gmail.com 


\section{REFERENCE}

Alexa.com. (2018, April 05). Top sites in Indonesia. Retrieved from https://www.alexa.com/topsites/countries/ID

Allern, S. (2002). Journalistic and commercial news values: News organizations as patrons of an institution and market actors. Nordicom Review, 1-2, 137-152. Retrieved from https://content.sciendo.com/view/journals/nor/23/1-2/article-p137.xml

Anderson, C. (2009). Web production, news judgment, and emerging categories of online newswork in metropolitan journalism. ISOJ.org. Columbia University Graduate School of Journalism. Retrieved from https://www.isoj.org/wpcontent/uploads/2018/01/Anderson09.pdf

Asosiasi Penyelenggara Jasa Internet Indonesia (APJII). (2019, April). Pengguna internet Indonesia tahun 2018. Retrieved from http://www.apjii.or.id/v2/read/content/infoterkini/301/pengguna-internet-indonesia-tahun-2014-sebanyak-88.html

Bardoel, J., \& Deuze, M. (2001). Network journalism': Converging competences of old and new. Australian Journalism Review, 23(2), 91-103.

Bednarek, M., \& Caple, H. (2017). The discourse of news values: How news organizations create newsworthiness. New York: Oxford university press.

Borden, S. (2013). Journalism as practice: Maclntyre, virtue ethics and the press. New York: Routledge.

Brighton, P., \& Dennis, F. (2007). News values. California: SAGE Publications.

Burns, L. S. (2012). Understanding journalism. London: SAGE.

Crain, R. (2008). In a consumer-controlled world, journalists should be marketers: Would help assess what readers want as they move across platforms. Advertising Age. Retrieved from https://adage.com/article/rance-crain/a-consumer-controlled-worldjournalists-marketers/126779/

Domingo, D., Masip, P., \& Meijer, I. C. (2015). Tracing digital news networks. Digital Journalism, 3, 53-67. https://doi.org/10.1080/21670811.2014.927996

Filak, V. F. (2015). Convergent journalism: An introduction (2nd ed.). Oxford: Focal Press.

Friedman, L. (2006). The world is flat. Jakarta: Dian Rakyat.

Fusco, M. (2010). An analysis of the competing business models of online journalism. Pennsylvania: Michael Fusco.

Given, L. M. (2008). The Sage encyclopedia of qualitative research methods. London: SAGE.

Harcup, T., \& O'Neill, D. (2016). What is News? News values revisited (again). Journalism Studies, 18(12), 1470-88. https://doi.org/10.1080/1461670X.2016.1150193

Hennink, M., Hutter, I., \& Bailey, A. (2010). Qualitative research methods. London: SAGE.

Hudson, G., \& Rowlands, S. (2018). The broadcast journalism handbook (2nd ed.). Essex: Routledge.

internetlivestats.com. (2018, April 5). Internet-users. Retrieved from http://www.internetlivestats.com/internet-users/

Kovach, B., \& Rosenstiel, T. (2014). The element of journalism: What people should know and the public should expect. New York: Three Rivers Press.

Kuwado, F. J. (2016, December 21). Dari 43.000 media "online", hanya 234 yang sesuai syarat UU Pers. Kompas.com. Retrieved from https://nasional.kompas.com/read/2016/12/21/19022441/dari.43.000.media.online .hanya.234.yang.sesuai.syarat.uu.pers

McKnight, D. (2013). Murdoch's politics: How one man's thirst for wealth and power shapes our world. London: Pluto Press. 
Muhammad Ruslan Ramli, \& Das'ad Latif. (2019). Pilihan isu dan ketidakberpihakan pemberitaan Mediaindonesia.com dan Voa-islam.com terhadap Reuni 212. Jurnal Komunikasi: Malaysian Journal of Communication, 35(4), 498-515.

Nugroho, Y., Syarief, S. S. (2012). Melampaui aktivisme click? Media baru dan proses politik dalam Indonesia kontemporer. Jakarta: Fesmedia Asia.

Pavlik, J. V. (2001). Journalism and new media. New York: Columbia University Press.

Quinn, S., \& Lamble, S. (2008). Online newsgathering: Research and reporting for journalism. Oxford: Focal Press.

Rasyid, A., \& Siagian, H. F. (2017). News value and reality: A case study. Jurnal Komunikasi: Malaysian Journal of Communication, 33(3), 55-69.

Septiawan Santana Kurnia, Siti Suriani Othman, Firmansyah, \& Engkus Kuswarno. (2020). Fact searching in investigative reporting in Indonesia: A case Study of Tempo and Gatra magazines. Jurnal Komunikasi: Malaysian Journal of Communication, 36(1), 298-316.

statista.com. (2018, April 5). Number of internet users in Indonesia. Retrieved from https://www.statista.com/statistics/254456/number-of-internet-users-in-indonesia/

Stray, H. (2009). What is news when the audience is the editor?. Retrieved from http://jonathanstray.com/papers/What\%20ls\%20News\%20When\%20the\%20Audien ce\%20is\%20Editor.pdf

Vivian, J. (2008). Teori komunikasi massa edisi 8. Minessota: Winona State University.

Ward, M. (2013). Journalism online. Oxford: Focal Press.

wearesocial.com. (2020, January). Digital 2020: Global digital overview. Retrieved from wearesocial.com: https://wearesocial.com/digital-2020

Wijaya, B. S. (2019). Dancing with the impropriety of media: How Indonesian consumers think and behave towards the unethical and illogical online news. Jurnal Komunikasi: Malaysian Journal of Communication, 35(1), 187-205.

Yang, G., \& Cannon, D. F. (2017). Proximity prominent news value for online publication. Newspaper Research Journal, 38(2), 259-270. 